\title{
MENUJU SISTEM HUKUM PERBURUHAN INDONESIA YANG BERKEADILAN
}

\author{
Asri Wijayanti \\ Universitas Muhamadiyah Surabaya \\ Email: asri1wj@yahoo.com
}

\begin{abstract}
Indonesia have no a fair of labor legal system. There are a conflict of interest between the workers the employers and the Government. The aim of this paper to show that the labor legal system are not already running. This paper based on normative research with statute approach and sociolegal. The studies showed that the first results, the substance of legal arrangements in the field of labor relations, in particular the minimum wages, outsourcing, and workers there are inconsistencies. The structure of labor law has not run. Second, the overlap of authority between the Ministry of Labour and the Ministry of Home Affairs in the field of labor related to regional autonomy. A legal vacuum in the legal effort to the problem of collective labor. Third, the legal culture in industrial relations better not run. Very necessary role of government in creating labor protection mechanism are based on ILO Conventions and Recommendations.
\end{abstract}

Key words: the labor legal system, substantive justice, industrial relations.

\begin{abstract}
Abstrak
Indonesia belum memiliki sistem hukum perburuhan yang adil. Terjadi dilema kepentingan buruh, pemberi kerja dan Pemerintah. Tulisan ini bertujuan membuktikan bahwa sistem hukum perburuhan belum berjalan. Tulisan ini berdasarkan hasil penelitian normatif dengan pendekatan statute approach dan sociolegal. Hasil penilitian menunjukkan bahwa pertama, substansi pengaturan hukum di bidang hubungan kerja, khususnya upah minimum, outsourcing dan TKI masih terdapat inkonsistensi. Struktur hukum perburuhan belum berjalan. Kedua, terjadi tumpang tindih kewenangan antara Kementrian Tenaga Kerja dan Kementrian Dalam Negeri di bidang perburuhan berkaitan dengan otonomi daerah. Terjadi kekosongan hukum dalam upaya hukum bagi masalah perburuhan kolektif. Ketiga, budaya hukum dalam hubungan industrial yang lebih baik belum berjalan. Sangat dibutuhkan peran pemerintah dalam menciptakan mekanisme perlindungan buruh yang berpijak pada Konvensi dan Rekomendasi ILO.
\end{abstract}

Kata kunci: sistem hukum perburuhan, keadilan substansi, hubungan industrial.

\section{Latar Belakang}

Maraknya demontrasi buruh di Indonesia dapat menimbulkan pemikiran tentang perlunya suatu sistem hukum perburuhan Indonesia yang berkeadilan. Penggunaan istilah "hukum perburuhan" dalam judul itu bukanlah suatu kesalahan atau kelalaian. Ada dua alasan pemilihan judul itu. Pertama, Departemen ruang lingkup hukum ketenagakerjaan adalah lebih luas daripada hukum perburuhan. Hukum perburuhan adalah hukum yang mengatur tentang hal- hal yang berkenaan dengan adanya hubungan kerja antara buruh/pekerja dengan majikan/pemberi kerja. Undang-undang Nomor 13 Tahun 2003 tentang Ketenagakerjaan yang selnjutnya disingkat UUK, mempersempit pengertian pemberi kerja hanya terbatas pada pengusaha saja. Antara aturan dan substansi UUK mengandung perbedaan. Seharusnya, apabila UUK dimaknai Ketenagakerjaan maka substansinya mengatur juga hubungan kerja 
yang dilakukan dalam lingkup informal, hubungan hukum antara negara dengan pegawainya dan militer. Realita yang ada tidak semua buruh/ pekerja dalam hubungan kerja mendapat perlindungan hukum berdasar UUK, hanya terbatas pada mereka yang bekerja pada pengusaha. Hal ini mengakibatkan buruh/pekerja informal tidak mendapat jaminan perlindungan hukum.

Kedua, Penekanan substansi makalah ini terletak pada "sistem hukum". Apakah sistem hukum Indonesia itu? Anglo Saxon, ataukah Eropa Kontinental? Sangat sulit untuk menjawab termasuk dalam klasifikasi sistem hukum manakah Indonesia. Indonesia tidak menggunakan salah satu dari dua poros sistem hukum dunia. Indonesia mendasarkan pada Pancasila. Hal ini mempunyai makna sistem hukum Indonesia harus dapat memadukan berbagai sistem hukum yang ada, yang sesuai dengan kepribadian bangsa. Selain dua sistem hukum Anglo Saxon dan Eropa Kontinental terdapat sistem hukum lainnya yaitu, sistem hukum agama (Islam, Budha, Hindu, Katolik/ Ptrotestan, sistem hukum kanonik), sistem hukum adat (Indonesia memiliki banyak lingkungan masyarakat hukum adat). Berangkat dari pemikiran itu, maka sangat dibutuhkan adanya sistem hukum perburuhan yang menjadi bagian dari sistem hukum Indonesia.

Kondisi perburuhan berkaitan erat dengan data kependudukan. Jumlah penduduk Indonesia berdasarkan sensus penduduk tahun 2010, adalah 237.641.326 orang ${ }^{1}$. Pada Agustus 2012, jumlah angkatan kerja adalah 120,4 juta orang. Jumlah penduduk yang bekerja sejumlah 110,8 juta orang. Tingkat Pengangguran Terbuka/TPT (perbandingan antara jumlah pencari kerja dengan jumlah angkatan kerja) menurut tingkat pendidikan di Indonesia pada Agustus 2012 mencapai 6,14 persen. ${ }^{2}$ Data tersebut menunjukkan tidak seimbangnya rasio antara lapangan kerja dengan jumlah tenaga kerja yang tersedia, mengakibatkan tingginya persaingan untuk memperoleh pekerjaan.

Upaya mengatasi pengangguran dengan investasi yang tetap dapat menjamin terselenggaranya hak dasar pekerja. Ada tiga kepentingan yang harus diperhatikan oleh legislator agar dalam membuat aturan hukum agar dapat mendorong terciptanya situasi yang kondusif. Kepentingan pertama dari sudut pandang buruh. Bagi buruh jaminan hak dasar pekerja dapat terlaksana dengan maksimal apabila Negara dapat mengurangi campur tangan yang membatasi. Negara harus menciptakan mekanisme dimana suatu aturan hukum dapat mewujudkan asas persamaan hak antara buruh dan pengusaha. Misalnya persamaan hak atas akses informasi guna meningkatkan kualitas buruh (serikat buruh) dalam melakukan perundingan. Kepentingan kedua yang harus diperhatikan adalah pengusaha. Bagi pengusaha, berlangsungnya usaha dan orientasi pasar menjadi dasar kepentingannya. Terciptanya good governance; jaminan keamanan; penegakan hukum akan merubah sikap pengusaha lebih terbuka menerima Serikat Buruh sebagai mitra usaha. Kepentingan ketiga yaitu Negara, mempunyai orientasi peningkatan kesejahteraan rakyat dan keamanan. Untuk itu perlu diperhatikan adanya harmonisasi pengaturan hukum perburuhan; harmonisasi hubungan antar lembaga serta harmonisasi antara pemerintahan pusat dan daerah.

Atas dasar tiga kepentingan itu maka ada dua parameter dasar dalam menyusun suatu sistem hukum perburuhan. Pertama makna perlindungan buruh, yaitu adanya jaminan pengaturan hak-hak dasar pekerja dan penegakan hukum atas aturan yang telah dibuat. Kedua makna orientasi pasar sebagai dasar pemenuhan kepentingan dasar bagi pemberi kerja. Disinilah sangat dibutuhkan peran pemerintah sebagai fasilitator. Membuat suatu mekanisme dalam bentuk perundang-undangan yang mengatur tentang substansi hukum perburuhan, menyelenggarakan suatu struktur yang tepat dan membuat mekanisme yang kondusif bagi terlaksananya budaya hukum.

Dari uraian di atas, maka yang menjadi permasalahan adalah bagaimana bentuk sistem hukum perburuhan yang berkeadilan. Metode penulisan yang digunakan dalam tulisan ini adalah normatif dan socio legal studies. Pendekatan normatif digunakan dengan melihat kesesuaian antara aturan hukum perburuhan berdasar lapisan

http://www.bps.go.id

2 Berita Resmi Statistik BPS, No.75/11/Th. XV, 5 November 2012. 
ilmu hukum, yaitu dogmatika hukum, teori hukum dan filsafat hukum. ${ }^{3}$ Selanjutnya penulisan ini juga menggunakan pendekatan socio legal studies, yaitu studi hukum yang menggunakan pendekatan metodologi ilmu sosial dalam arti luas. Merupakan pendekatan alternatif yang menguji studi doktrinal terhadap hukum perburuhan. Langkah yang dilakukan dalam penelitian ini adalah studi tekstual, dengan menganalisis aturan dan kebijakan hukum yang selanjutnya dianalisis secara kritikal dan dijelaskan makna dan implikasinya terhadap subjek hukum. Apakah aturan atau kebijakan itu menguntungkan atau merugikan kelompok masyarakat tertentu, dalam hal ini adalah terhadap buruh. ${ }^{4}$

\section{Pembahasan}

Friedman memberikan tiga komponen sistem hukum yaitu substansi hukum, struktur hukum dan budaya hukum. ${ }^{5}$ Untuk itulah kajian selanjutnya mendasarkan pada tiga komponen atau unsur dari sistem hukum.

\section{a. Substansi Hukum Perburuhan}

Unsur pertama dari sistem hukum perburuhan adalah substansi hukum perburuhan. Substansi hukum perburuhan adalah Peraturan Perundangundangan tentang perburuhan. Harus terdapat kesesuaian peraturan, diantaranya terdapat sinkronisasi vertikal dan horisontal antar aturan hukum perburuhan. Kesesuaian itu harus berdasarkan lapisan ilmu hukum. Sesuai antara aturan hukum dengan teori hukum dan filsafat hukum. Berkaitan dengan hal itu muncul pertanyaan:

1. Apakah aturan hukum perburuhan Indonesia sudah konsisten? Pertanyaan ini menunjuk pada kajian dogmatika hukum.

2. Apakah aturan hukum perburuhan Indonesia sudah benar? Pertanyaan ini menunjuk pada kajian teori hukum

3. Apakah aturan hukum perburuhan Indonesia sudah adil bagi pekerja, pemberi kerja (tidak hanya pengusaha) dan negara (bertindak untuk rakyat)? Pertanyaan ini menunjuk pada kajian filsafat hukum.
Terhadap masalah pertama, kondisi peraturan perburuhan Indonesia, masih terdapat beberapa aturan hukum yang belum konsisten. Terdapat aturan hukum perburuhan yang inkonsistensi baik secara vertikal (antar Peraturan Perundang-undangan yang rendah dan yang tinggi) maupun horisontal (antar Peraturan Perundang-undangan yang secara hierarkis sederajat). Contoh pengaturan upah minimum, sistem kerja outsourcing, Tenaga Kerja Indonesia (TKI), dualisme aturan hubungan kerja, tidak dipisahkannya individual employment law, collective labour law dan sosial security law.

Terdapat inkonsistensi vertikal pada pengaturan upah minimum, Perlindungan terhadap tiap-tiap upah pekerja bersumber pada Pasal 27 ayat (2) UUD 1945 yaitu tiap-tiap warga negara berhak atas pekerjaan dan penghidupan yang layak bagi kemanusiaan dan Pasal 28 D ayat (2) UUD 1945 yaitu setiap orang berhak untuk bekerja serta mendapat imbal an dan perlakuan yang adil dan layak dalam hubungan kerja. Penjabaran upah yang adil dan layak dalam hubungan kerja adalah penghasilan yang layak bagi kemanusiaan (Pasal 88 ayat (1) UU Nomor 13 Tahun 2003). Upah didefinisikan sebagai: hak pekerja/buruh yang diterima dan dinyatakan dalam bentuk uang sebagai imbalan dari pengusaha atau pemberi kerja kepada pekerja/buruh yang ditetapkan dan dibayarkan menurut suatu perjanjian kerja, kesepakatan atau Peraturan Perundang-undangan termasuk tunjangan bagi pekerja/buruh dan keluarganya atas suatu pekerjaan dan/atau jasa yang telah atau akan dilakukan. (Pasal 1 angka 30 UU Nomor 13 Tahun 2003). Ketentuan ini tidak dijabarkan lebih lanjut di dalam peraturan pelaksana. Besaran upah minimum tergantung pada kebutuhan hidup layak (KHL). KHL adalah standar kebutuhan seorang pekerja/buruh lajang untuk dapat hidup layak secara fisik untuk kebutuhan 1 (satu) bulan (Pasal 1 angka 1 Permenakertrans Nomor 13 Tahun 2012 tentang Komponen dan Pelaksanaan Tahapan Pencapaian Kebutuhan Hidup Layak). Inkonsistensi vertikal ini juga berakibat adanya pelanggaran teori hukum tentang upah yang layak. Article

3 Wijayanti, Strategi Belajar Argumentasi Hukum, Lubuk Agung, Bandung, 2012.

4 Sulistyowati Irianto, Metode Penelitian Hukum: Konstelasi dan Refleksi, Yayasan Obor Indonesia, Jakarta, 2009, hlm. 175-178.

5 Lawrence M. Friedman, American Law an Introduction, W.W. Norton and Co., New York, 1998, hlm.6-10. 
3 Konvensi ILO Nomor 131 adalah:

The elements to be taken into consideration in determining the level of minimum wages shall, so far as possible and appropriate in relation to national practice and conditions, include :

(a) the needs of workers and their families, taking into account the general level of wages in the country, the cost of living, sosial security benefits, and the relative living standards of other sosial groups;

(b) economic factors, including the requirements of economic development, levels of productivity and the desirability of attaining and maintaining a high level of employment.

Apabila suatu aturan hukum bertentangan dengan teori hukum yang sudah diakui sifat universalnya, maka besar kemungkinan terjadi pelanggaran filsafatinya. Pemberian upah yang adil bagi pekerja/buruh belum dapat tercapai. Kesalahan pengaturan tentang upah minimum dalam tataran dogmatika hukum, teori hukum dan filasafat hukum mengakibatkan salah satu tuntutan buruh secara nasional, yaitu "tolak upah murah".

Contoh kedua adalah terjadinya inkonsistensi substansi dalam pengaturan outsourcing atau dapat disebut "alih daya". Outsourcing berasal dari teori ekonomi yang bertujuan untuk mencapai efisiensi kerja dibandingkan apabila menggunakan in house manufacturing. Dari segi tinjauan teori hukum, outsourcing adalah bentuk pemborongan pekerjaan. Pasal 64-66 UUK telah salah memberikan batasan outsourcing yang memperluas pengertian outsourcing ke dalam bentuk outsourcing pekerja (bukan outsourcing pekerjaan). Lebih lanjut, dalam tataran praktik hukum terdapat putusan Mahkamah Konstitusi Nomor 27/PUU-IX/2011, yang memutuskan Pasal 66 ayat (2) huruf b UU Nomor 13 Tahun 2003 adalah bertentangan secara bersyarat dengan UUD 1945 (conditionaly unconstitutional).

Putusan ini mengakibatkan terjadinya peralihan kewajiban subjek hukum dalam konsep hubungan kerja. Adanya kewajiban pengalihan perlindungan hak-hak pekerja/buruh yang obyek kerjanya tetap ada walaupun terjadi pergantian perusahaan yang melaksanakan sebagian pekerjaan borongan dari perusahaan lain atau perusahaan penyedia jasa pekerja/buruh. Ada dua pertimbangan hukum yang melandasi putusan tersebut yaitu adanya syarat perjanjian antara pekerja dengan perusahaan yang melaksanakan pekerjaan tidak berbentuk Perjanjian Kerja Waktu Tertentu (PKWT) dan penerapan prinsip pengalihan tindakan pengalihan perlindungan bagi pekerja/buruh (Transfer of Undertaking Protection of Employment/ TUPE) yang dilandasi pemikiran nondiskriminasi dalam penerimaan fair benefit and welfare bagi pekerja.

Putusan MK Nomor 27/PUU-IX/2011, pada awalnya ditindak lanjuti dengan Surat Edaran (SE) Menteri Nomor B.31/PHIJSK/2012 tentang Outsourcing dan Perjanjian Kerja Waktu Tertentu (PKWT). Surat Edaran bukanlah aturan hukum. SE ditujukan untuk intern kelembagaan Kemenakertrans, bukan ditujukan untuk umum. SE sifatnya tidak mengikat karena hanya himbauan, dapat dilaksanakan atau tidak dilaksanakan tidak ada sanksinya. SE tidak termasuk dalam hierarki Peraturan Perundang-undangan Indonesia sebagaimana dalam UU Nomor 12 Tahun 2011 tentang Pembentukan Peraturan Perundangundangan. Jadi SE tidak mempunyai kekuatan hukum. Berkaitan dengan hal ini tepatlah tuntutan Mayday 2012 yaitu "terbitkan Peraturan Pemerintah atau Peraturan Menteri yang melarang outsourcing tenaga kerja".

Muatan putusan MK Nomor 27/ PUU-IX/2011 dan SE Menaker Nomor B.31/ PHIJSK/2012, menimbulkan polemik. Terjadi demo terus menerus secara nasional untuk "hapuskan outsourcing". Atas dasar kondisi perburuhan ini, maka Menakertrans mengeluarkan Permenakertrans Nomor 19/2012 yang membatasi hanya ada lima jenis pekerjaan penunjang yang dapat dilakukan dengan sistem kerja outsourcing, yakni security, catering, cleaning service, transportasi, dan penunjang pekerjaan pertambangan dan perminyakan. Ketentuan ini menunjukkan bahwa negara telah mencampuri urusan privat. Seharusnya yang berhak menentukan pekerjaan inti atau penunjang hanyalah pemberi kerja bukan orang lain termasuk negara.

Selanjutnya, dengan mendasarkan pada Permenakertrans Nomor 19/2012, timbul demo buruh secara nasional untuk merubah status hubungan kerja outsourcing bagi jenis pekerjaan (yang tidak termasuk dalam jenis pekerjaan penunjang yang dapat dilakukan dengan sistem kerja 
outsourcing, yakni security, catering, cleaning service, transportasi, dan penunjang pekerjaan pertambangan dan perminyakan) menjadi status pekerja/buruh tetap. Di berbagai daerah demo ini sempat menimbulkan tindakan anarkis. Tidak ada keadilan substansi bagi pemberi kerja untuk mendapatkan jaminan atas kebebasan berusaha. Tidak ada pilihan bagi pemberi kerja untuk mengatur cara kerjanya. Seharusnya Negara menjamin kebebasan berusaha bagi pemberi kerja untuk menentukan bagian dari rangkaian pekerjaannya yang sangat penting, penting, kurang penting dan tidak penting. Kriteria tingkat kepentingan dari sebagian pekerjaan hanya dapat didasarkan pada sisi originalitas dari hasil pekerjaan. Berkaitan dengan hal ini, tidaklah salah apabila muncul anggapan bahwa "Negara mempunyai andil yang sangat besar dalam menciptakan konflik sosial".

Contoh ketiga adalah Tenaga Kerja Indonesia (TKI) (menurut penulis seharusnya istilah yang tepat adalah overseas worker bukan migrant worker). Perlindungan hukum terhadap TKI oleh Indonesia hanya dapat dilakukan pada masa pra penempatan dan pasca penempatan. UU Nomor 39 Tahun 2004 juga mengatur perlindungan hukum saat masa penempatan. Dalam hal ini, perlu diingat bahwa hukum perburuhan adalah hukum yang bersifat fungsional. Pada masalah TKI ini, hukum perburuhan harus tunduk pada kaedah atau prinsip hukum internasional. Salah satu prinsip hukum internasional adalah adanya asas yurisdiksi negara. Menjadi pertanyaan apakah aturan tentang TKI adalah benar dengan tidak mengindahkan yurisdiksi negara dimana TKI bekerja? Tentu jawabnya adalah tidak benar. Tidak adil bagi negara lain tempat TKI bekerja harus tunduk pada aturan Indonesia.

Dari tiga contoh itu tampak bahwa substansi hukum perburuhan Indonesia masih belum sempurna. Masih terdapat inkonsistensi vertikal dan horisontal dalam dogmatika hukum, ketidak benaran berdasar teori hukum dan ketidak adilan dalam kajian filsafat hukum. Hukum perburuhan kita belum membedakan Individual Employment Law-Collective Labour Law dan Sosial Security Law.
Substansi hukum yang kurang memperhatikan kaedah teori hukum dan filsafat hukum, mengakibatkan adanya anggapan yang salah terhadap nilai hukum. Hukum hanya diartikan sepenggal terbatas pada kepastian hukum, bukan keadilan substansinya. Bismar Siregar memandang hal ini sebagai suatu kesalahan pendidikan hukum di Indonesia. ${ }^{6}$ Kesalahan itu harus secepatnya diperbaiki. Peran legal scholarship teramat penting. Ahli hukum, pemerhati hukum, pengkaji hukum dan penegak hukum harus menganggap hukum sebagai suatu sistem yang terbuka. Hukum yang adil adalah hukum yang baik apabila memenuhi 8 principles of legality, yaitu :

1. a failure to achieve rules at all, so that every issue must be decided on an ad hoc basis;

2. a failure to publicize, or at least to make avaiable to the affected party, the rules he is expected to observe;

3. the abuse of retoactive legislation, which not only cannot itself guide action, but under cuts the integrity of rules prospective in effect, since it puts them under the threat of retrospective change;

4. a failure to make rules understandable;

5. the enactment of contradictory rules;

6. rules that require conduct beyond the powers of the affected party;

7. introducing such frequent changes in the rules that the subject cannot orient his action by them;

8. a failure of congruence between the rules as announced and their actual adminisration. ${ }^{7}$

\section{b. Struktur Hukum Ketenagakerjaan}

Unsur sistem hukum yang kedua adalah struktur hukum perburuhan. Unsur kedua ini meliputi pranata/lembaga yang berwenang menangani masalah perburuhan. Struktur kita belum bagus. Tampak tumpang tindih kewenangan, atau kekosongan kewenangan. Kelembagaan berkaitan dengan jabatan publik. Terjadi tumpang tindih kewenangan antara Menteri Tenaga Kerja dan Menteri Dalam Negeri di bidang perburuhan berkaitan dengan otonomi daerah.

\footnotetext{
6 Antonius Sudirman, Hati Nurani Hakim dan Putusannya, Suatu Pendekatan dari Prespektif Ilmu Hukum Perilaku (Behavioral Jurisprudence) Kasus Bismar Siregar, Bandung: Citra Aditya, 2007, hlm. 119.

7 Lon L Fuller, The Morality Of Law, Yale University Pres, 1975, hlm. 39.
} 
Hukum perburuhan merupakan hukum yang fungsional. Pada awalnya memang berasal dari hukum perdata karena adanya hubungan kerja berdasar perjanjian kerja, dimana perjanjian kerja adalah bagian dari hukum kontrak (perdata). Adanya ketimpangan kedudukan buruh dan pemberi kerja mengharuskan negara aktif melakukan perlindungan hukum melalui mekanisme Peraturan Perundang-undangan. Turut campurnya negara ke dalam hukum perburuhan menjadikan hukum perburuhan menjadi lingkup hukum administrasi. Adanya kemungkinan pelanggaran hak dasar atas kebebasan dan hak hidup memaksa adanya sanksi pidana dalam pelanggaran hak dasar pekerja. Oleh karena itu hukum perburuhan juga masuk dalam hukum pidana. Perkembangan lebih lanjut, kajian hukum perburuhan dapat menjadi bagian dari hukum bisnis, hukum lingkungan, hukum pajak, hukum internasional. Inilah bukti bahwa hukum merupakan suatu sitim yang saling kait mengait antar unsur-unsurnya. Hukum adalah suatu ilmu yang interdisipliner.

Lebih lanjut, timbul pertanyaan, apakah struktur hukum perburuhan sudah berjalan sesuai sistemnya? Untuk menjawabnya perlu dipikirkan lebih dalam. Contoh masalah upah minimum. Pelanggaran terhadap pembayaran upah yang lebih rendah daripada upah minimum adalah perbuatan kejahatan dengan ancaman sanksi pidana penjara paling singkat 1 (satu) tahun dan paling lama 4 (empat) tahun dan/atau denda paling sedikit Rp 100.000.000,00 (seratus juta rupiah) dan paling banyak Rp 400.000.000,00 (empat ratus juta rupiah) (Pasal 90 ayat (1) jo. Pasal 185 ayat(1) UU Nomor 13 Tahun 2003). Atas aturan ini timbul pertanyaan, siapakah yang berwenang melakukan penangkapan terhadap pengusaha yang melanggar? Pegawai Disnaker kota/provinsi ataukah kepolisian? Dalam kasus ini kedua lembaga tampaknya saling melempar untuk tidak bertindak. Seharusnya berdasar asas legalitas, apa yang tertulis dalam Undang-undang menjadikan penegak hukum (polisi) untuk bertindak. Mengapa polisi tidak bertindak? Ada argumen substansi sistem hukum yang membenarkan bahwa kriteria pengusaha masih kabur. Berapa besar modal pengusaha yang terikat dengan ketentuan Pasal 90 ayat (1) jo. Pasal 185 ayat(1) UU Nomor 13 Tahun 2003? Demikian juga dengan pegawai pengawas ketenagakerjaan. Bukannya yang diatur berkaitan dengan ketidak mampuan membayar sesuai upah minimum hanyalah sarana ijin penangguhan untuk membayar upah minimum.

Lebih lanjut, bagaimana apabila ketentuan upah minimum tidak diterima oleh salah satu unsur dewan pengupahan, yaitu APINDO. Kemana gugatan upah minimum ditujukan? Tahun 2011, gugatan terhadap SK Gubernur Bekasi dimenangkan oleh Apindo. Mengapa? Kompetensi absolut PTUN hanyalah KTUN yang bersifat konkrit individual dan formil. Gugatan terhadap upah minimum tidak memenuhi unsur individual. Mengapa tidak ditujukan ke Pengadilan Hubungan Industrial? PHI tidak mempunyai kompetensi terhadap perselisihan perburuhan yang bersifat publik. Secara logika peradilan umum seharusnya menangani kasus yang tidak dapat diperiksa dan diadili oleh pengadilan khusus. Sayangnya kompetensi Pengadilan Negeri yang merupakan bentuk peradilan umum hanya mempunyai kompetensi absolut perdata dan pidana. Bukan publik dan privat. Hal ini seharusnya menjadi perhatian bagi legal scholarship.

Selain itu masalah struktur hukum perburuhan, juga terkendala dengan adanya otonomi daerah. Kepala daerah yang menyalahgunakan kewenangannya dapat melakukan tekanan pada Kepala Dinas Tenaga Kerja di tingkat kabupaten/ kota untuk memutasi pegawai pengawas perburuhan yang amanah dalam bekerja, apabila hasil pengawasannya merugikan kepentingan pribadi dari kepala daerah. Sebagai contoh di salah satu daerah di luar pulau Jawa, terdapat perusahaan yang terbukti melanggar norma perlindungan pekerja. Setelah pegawai pengawas memberikan berita acara pelanggaran kepada perusahaan yang melanggar, pegawai pengawas di mutasi ke daerah lain. Tugas pengawasan diambil alih oleh Kadisnaker yang tidak menjabat pegawai pengawas. Selanjutnya terjadi pencabutan berita acara oleh Kadisnaker tersebut. Mengapa hal ini dapat terjadi? Tentunya sangat dipengaruhi oleh faktor kualitas spiritual kepala daerah itu. Ternyata pemilik perusahaan yang melanggar adalah anak dari kepala daerah. ${ }^{8}$ 


\section{c. Budaya Hukum}

Kajian unsur sistem hukum yang ketiga adalah budaya hukum. Kesesuaian perilaku masyarakat terhadap kehendak Undang-undang (Peraturan Perundang-undangan). Yang menjadi arti penting dalam budaya hukum adalah perilaku masyarakat. Bagaimana perilaku buruh/pekerja, pemberi kerja, pemerintah di dalam hubungan perburuhan? Apakah buruh mempunyai etos kerja yang tinggi sebagai wujud dari ibadah? Apakah pemberi kerja telah memberikan hak-hak pekerja tepat waktu dan benar? Apakah pemberi kerja sudah mengamalkan "bayarlah upah buruhmu sebelum kering keringatnya? Apakah pemerintah telah membuat mekanisme ketenangan kerja, terbuka dan bertanggung jawab, dijamin tidak ada biaya siluman? Apakah kepastian hukum dapat ditegakkan oleh hakim?

Berbagai pertanyaan itu sepertinya sudah kita ketahui bersama jawabya adalah "belum". Mengapa? Budaya hukum tegantung pada jiwa seseorang. Jiwa yang baik, tidak akan pernah mengambil hak orang lain. Seharusnya pendekatan spritual menjadi ruh dalam setiap hubungan hukum. Fakta yang ada di awal tahun 2012 di Tangerang-Jakarta-Bekasi, buruh tidak mentaati putusan Pengadilan Tata Usaha Negara Bekasi. Bukan yudisial yang dipilih oleh buruh untuk memperjuangkan haknya yang terlanggar. Buruh memilih alternatif penyelesaian dalam bentuk non yudisial yaitu menutup jalan tol. Penutupan jalan tol oleh buruh untuk mendapatkan upah minimum sesuai SK Gubernur Bekasi bukan putusan pengadilan merupakan suatu bentuk shoping forum yang dikenal dalam socilegal. Penutupan jalan tol sering dikatakan sebagai bentuk upaya "Nglurug" (apakah sama dengan mogok, demonstrasi, unjuk rasa). "Nglurug" seharusnya tidak dapat berdiri sendiri tanpa lanjutannya yaitu "Nglurug tanpo bolo menang tanpo ngasorake”. Pepatah ini adalah berasal dari filosofi yang menjadi bagian dari sistem hukum adat Jawa. Sangat penting makna musyawarah, tanpa merendahkan lawan kita. Tampaknya filososfi sudah disalah artikan dalam hubungan perburuhan. Inilah bukti bahwa sistem hukum perburuhan Indonesia belum sempurna.

Mekanisme keterbukaan sudah dirumuskan oleh $I L O$ berkaitan dengan prinsip transparansi dalam kebebasan berserikat. Prinsip transparansi adalah keterbukaan. Terkandung hak untuk mendirikan organisasi (Pasal 2 Konvensi ILO
Nomor 87), menyusun konstitusi (Anggaran Dasar) bagi Serikat Pekerja (Pasal 3 Konvensi ILO Nomor 87), mengatur administrasi, kegiatan dan menyusun program (Pasal 3 Konvensi ILO Nomor 87). Kewajiban negara untuk mengambil langkah (secara legal) untuk menjamin hak berserikat (Pasal 11 Konvensi ILO Nomor 87) jo (Pasal 3 Konvensi ILO Nomor 98) dengan memfasilisitasi perundingan bersama (Pasal 4 Konvensi ILO Nomor 98) jo (Pasal 1 Rekomendasi ILO Nomor 91) jo (Pasal 5 Konvensi ILO Nomor 154) (Pasal 2 Rekomendasi ILO Nomor 163) ke dalam aturan hukum. Negara dapat membentuk peraturan tentang terbentuknya badan konsultasi dan kerjasama yang mendukung kondisi tercapainya perundingan bersama (Pasal 2 Rekomendasi ILO Nomor 94); memberikan pelatihan kepada negosiator di semua tingkatan (Pasal 5 Rekomendasi ILO Nomor 163); memberikan informasi keadaan sosial ekonomi tidak merugikan kepentingan nasional (Pasal 7 Rekomendasi ILO Nomor 163). Selain itu negara dapat membentuk peraturan tentang komunikasi antara manajemen dan pekerja di dalam usaha (Pasal 1 Rekomendasi ILO Nomor 129) yang mendasarkan pada iklim saling pengertian dan kepercayaan untuk efisiensi dan aspirasi buruh (Pasal 2 Rekomendasi ILO Nomor 129) berupa :

1. pertukaran informasi yang objektif (Pasal 2 Rekomendasi ILO Nomor 129);

2. tidak akan menyebabkan kerusakan pada salah satu pihak (Pasal 3 Rekomendasi ILO Nomor 129);

3. penggunaan metode yang tidak bertentangan dengan kebebasan berserikat (Pasal 4 Rekomendasi ILO Nomor 129);

4. bertujuan untuk langkah-langkah perbaikan (Pasal 5 Rekomendasi ILO Nomor 129);

5. disesuaikan dengan kondisi perusahaan dan kepentingan buruh (Pasal 8 Rekomendasi ILO Nomor 129)

Kewajiban pengusaha adalah memberikan informasi keadaan sosial ekonomi yang menjadi dasar perundingan bersama. (Pasal 7 Rekomendasi ILO Nomor 163). Pengusaha dapat menciptakan sarana yang dapat mendukung perundingan melalui pertemuan, ada media (dengan sasaran :kelompok, individual) sarana peran serta (Pasal 13 Rekomendasi ILO Nomor 129). Jenis informasi yang sangat dibutuhkan untuk keberhasilan 
perundingan bersama adalah: kondisi kerja umum, termasuk mutasi dan pemutusan hubungan kerja; deskripsi pekerjaan dan tempat pekerjaan tertentu dalam struktur usaha; kemungkinan pelatihan dan prospek kemajuan dalam usaha; kondisi kerja umum; peraturan keselamatan dan kesehatan kerja serta petunjuk untuk pencegahan kecelakaan dan penyakit kerja; prosedur pemeriksaan keluhan; personil pelayanan kesejahteraan (perawatan medis, kesehatan, kantin, perumahan, rekreasi, tabungan dan fasilitas perbankan, dan lain-lain); jaminan sosial atau skema bantuan sosial dalam usaha; peraturan program jaminan sosial nasional yang dikenakan para pekerja berdasarkan pekerjaan mereka dalam usaha; situasi umum dari usaha dan prospek atau rencana untuk pembangunan masa depan; penjelasan tentang keputusan yang mungkin langsung atau tidak langsung mempengaruhi situasi pekerja di usaha; metode diskusi dan konsultasi dan kerjasama antara manajemen dan wakil-wakilnya di satu pihak dan para pekerja dan wakil-wakil mereka di sisi lain. (Pasal 15 Rekomendasi ILO Nomor 129). Prinsip keterbukaan mengandung makna isi (substansi) dan prosedur menjadi dasar bagi buruh/Serikat Buruh dan pengusaha untuk menumbuhkan rasa saling pengertian dan kepercayaan. Adanya keterbukaan menjadi dasar dalam memperkecil terjadinya perselisihan perburuhan dan mewujudkan ketenangan kerja.

\section{Kesimpulan}

Indonesia belum memiliki sistem hukum perburuhan yang tepat, UU Nomor 13 Tahun 2003 belum mengatur tentang substansi, struktur dan upaya penciptaan budaya hukum secara terpadu. Substansi hukum perburuhan masih diwarnai inkonsistensi vertikal dan horisontal. Permenakertrans Nomor 13/2012 bertentangan dengan Pasal 88 ayat (1) UU Nomor 13 Tahun 2003 jo. Pasal 27 ayat (2) jo. Pasal 28 D ayat (2) UUD 1945. Pengaturan outsourcing tidak sesuai dengan teori hukum. Permenakertrans Nomor 19/2012 jo. Pasal 64-66 UU Nomor 13 Tahun 2003 bertentangan dengan Pasal 28 D ayat (2) UUD 1945 dan teori hukum. Struktur hukum perburuhan masih tumpang tindih atau terjadi kekosongan kewenangan. Terjadi tumpang tindih kewenangan antara Menteri Tenaga Kerja dan Menteri Dalam Negeri di bidang perburuhan berkaitan dengan otonomi daerah. Pengaturan penegakan hukum atas pelanggaran upah minimum tidak jelas menjadi kewenangan Pegawai Disnaker kota/ provinsi atau kepolisian. Sarana upaya hukum atas pelanggaran upah minimum belum menjadi kompetensi PHI. PHI tidak mempunyai kompetensi terhadap perselisihan perburuhan yang bersifat publik. Belum tercipta budaya hukum yang mengutamakan musyawarah serta belum terciptanya mekanisme aturan perburuhan yang kondusif. Belum terdapat kesesuaian perilaku masyarakat (buruh/pekerja, pemberi kerja, pemerintah) terhadap kehendak Undang-undang (Peraturan Perundang-undangan). Mekanisme shopping forum lebih dipilih pekerja atas upaya pencapaian hak dasar pekerja sesuai core convention ILO. Pemerintah belum mampu menciptakan mekanisme pengaturan atas jaminan penegakan core convention.

\section{DAFTAR PUSTAKA}

\section{Buku}

Antonius Sudirman, 2007, Hati Nurani Hakim dan Putusannya, Suatu Pendekatan dari Prespektif Ilmu Hukum Perilaku (Behavioral Jurisprudence) Kasus Bismar Siregar, Citra Aditya, Bandung.

Berita Resmi Statistik BPS, Nomor75/11/Th. XV, 5 November 2012.

Friedman, Lawrence M., 1998, American Law an

Introduction, W.W. Norton and Co., New York.
Lon L Fuller, 1975, The Morality Of Law, Yale University Pres, Yale.

Sulistyowati Irianto, 2009, Metode Penelitian Hukum: Konstelasi dan Refleksi, Yayasan Obor Indonesia, Jakarta.

Wijayanti, 2012, Strategi Belajar Argumentasi

Hukum, Lubuk Agung, Bandung.

\section{Artikel Internet}

http://www.bps.go.id. 